\title{
Evaluation of serum lipid profile in cases of pre-eclampsia and eclampsia
}

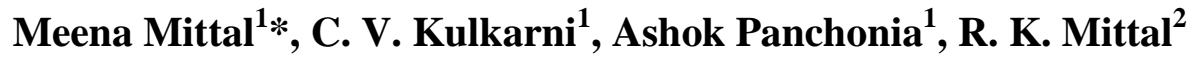 \\ ${ }^{1}$ Department of Pathology, MGM Medical College, Indore, M.P., India \\ ${ }^{2}$ Consultant Physician, Indore, M.P., India
}

Received: 11 August 2014

Accepted: 19 August 2014

\section{* Correspondence:}

Dr. Meena Mittal,

E-mail: meenamittal10@gmail.com

(C) 2014 Mittal M et al. This is an open-access article distributed under the terms of the Creative Commons Attribution Non-Commercial License, which permits unrestricted non-commercial use, distribution, and reproduction in any medium, provided the original work is properly cited.

\begin{abstract}
Background: According to the current knowledge, rise in the serum triglyceride level is a major contributor in the pathogenesis of preeclampsia and eclampsia. The present study was designed to compare the changes in lipid profile in normal pregnancy, pre-eclampsia \& eclampsia cases.

Methods: A case control study was done consisting of total 100 study subjects, 75 already diagnosed pre-eclamptic \& eclamptic women and 25 normotensive pregnant women. Age range was 18-35 years, gestational age 28 weeks to term were included. Serum Total Cholesterol (TC), triglyceride and HDL-cholesterol by enzymatic colorimetric method were done.

Results: Results showed that level of serum triglycerides in mild pre-eclampsia $(156.22 \pm 66.5 \mathrm{mg} / \mathrm{dl})$, severe preeclampsia $(168.30 \pm 68.1 \mathrm{mg} / \mathrm{dl}) \&$ eclampsia $(224.89 \pm 84.40 \mathrm{mg} / \mathrm{dl})$ as compared to normal pregnant women $(130.95 \pm 44.64 \mathrm{mg} / \mathrm{dl})$ was increased significantly $(\mathrm{P}<0.05)$. Other parameters $\mathrm{TC}$, HDL-C, LDL-C were not changed significantly.

Conclusions: The findings of the present study are consistent with previous studies, suggesting increased levels of serum triglyceride as an important factor in the pathological process of preeclampsia \& eclampsia. This may help in developing strategies for prevention or early diagnosis of the disorder.
\end{abstract}

Keywords: Pre-eclampsia, Triglycerides, High density lipoproteins, Low density lipoproteins

\section{INTRODUCTION}

Pre-eclampsia \& eclampsia is one of the most common complications of pregnancy. In India the incidence of Pre-eclampsia is reported to be $8-10 \%$ of pregnancy. ${ }^{1}$ It is a cause of high morbidity for both mother \& fetus, especially in developing countries. ${ }^{2}$

Pre-eclampsia is a multisystem disorder characterized by hypertension to the extent of $140 / 90$ or more, proteinuria ( $\geq 300 \mathrm{mg} /$ day) \& edema induced by pregnancy after $20^{\text {th }}$ week. ${ }^{3}$ Without intervention, pre-eclampsia progresses to eclampsia which is characterized by malignant Hypertension \& epileptiform convulsions requiring emergency caesarean section. ${ }^{4}$
Despite considerable research, the cause or causes of preeclampsia remain unclear and there are no clinically useful screening test to identify women in whom it will develop. ${ }^{5}$

Pre-eclampsia \& related disorders are known to affect function of various organs involved in lipid \& lipoprotein metabolism. Several studies have shown that endothelial dysfunction is related to hyperlipidemia., ${ }^{6,7}$

Disorders of lipoprotein metabolism are reported to be a major cause of hypertension and proteinuria in preeclampsia. 
In view of the above findings it is postulated that alteration of lipid metabolism may play a key role in the development of symptoms of pre-eclampsia \& eclampsia.

In this context, the present study has been undertaken to compare the changes in lipid profile in normal pregnancy, pre-eclampsia and eclampsia.

\section{METHODS}

The present study was carried out in the department of pathology in collaboration with department of obstetrics and gynecology, M.G.M. medical college and M.Y. hospital, Indore.

Informed consent was taken from all individual subjects inducted into the study. Total 100 pregnant women of 1835 years, were selected and grouped as follows group-I (controls): 25 normotensive pregnant women: group-II (cases) 75 (a1) 21 mild pre-eclamptic (a2) 28 severe preeclamptic (i.e. total 49 cases of pre-eclampsia) and (b) 26 eclamptic subjects.

Exclusion criteria-pre-existing hypertension, IHD, CRF, $\mathrm{DM}$, treatment with drugs may influence lipid profile. The pre-eclamptic patients were diagnosed by the presence of persistent hypertension (more than 140/90 $\mathrm{mm}$ of $\mathrm{Hg}$ ), gross proteinuria (tested by heat test of urine), and pathological edema. In mild pre-eclampsia BP exceeds 140/90 $\mathrm{mm}$ of $\mathrm{Hg}$. And in severe pre-eclampsia BP exceeds $160 / 110 \mathrm{~mm}$ of $\mathrm{Hg}$. In mild pre-eclampsia proteinuria may be trace to $1+$ and in severe preeclampsia proteinuria of $2+$ or more. The eclamptic patients were diagnosed by the additional feature of convulsion or coma. Fasting blood samples were collected; the serum was separated and analyzed for the following parameters.

Triglycerides were measured by GOP-PAP method. Total cholesterol and HDL cholesterol were measured by CHOD-PAP method and low density lipoprotein cholesterol (LDL-cholesterol) were calculated - by
Friedwald's formula. Statistical analysis was done using the unpaired T-test and Pearson's correlation.

\section{RESULTS}

Demographic \& clinical characteristic of control \& study groups are shown in Table 1 .

Lipid profiles of control \& study groups are shown in Table 2. The mean value of serum triglycerides (TG) in study and control groups were mild pre-eclampsia $(156.22 \pm 66.5 \mathrm{mg} / \mathrm{dl})$ severe preeclampsia (168.30 \pm $68.1 \mathrm{mg} / \mathrm{dl})$ \& eclampsia $(224.89 \pm 84.40 \mathrm{mg} / \mathrm{dl})$ as compared to normal pregnant women $(130.95 \pm 44.64$ $\mathrm{mg} / \mathrm{dl})$ which was increased significantly $(\mathrm{P}<0.05)$ as shown in Table 2.

While mean cholesterol level, mean high density lipoproteins cholesterol, mean LDL cholesterol were not statistically different between pre-eclamptic, eclamptic and normal subjects as shown in Table 2.

Table 1: Demographic \& clinical characteristic of control \& pre-eclamptic \& eclamptic subjects.

\begin{tabular}{|lll|}
\hline Parameters & $\begin{array}{l}\text { Group I } \\
\text { Control }\end{array}$ & $\begin{array}{l}\text { Group II } \\
\text { Cases }\end{array}$ \\
\hline $\begin{array}{l}\text { Maternal age (year) } \\
\text { mean } \pm \text { SD }\end{array}$ & $21.20 \pm 2.47$ & $24.19 \pm$ \\
\hline Primigravida & 11 & 54 \\
\hline Multi gravid & 14 & 21 \\
\hline $\begin{array}{l}\text { Gestational age } \\
\text { (weeks) mean } \pm \mathrm{SD}\end{array}$ & $29.84 \pm 7.96$ & $34.8 \pm 4.19$ \\
\hline $\begin{array}{l}\text { Systolic BP }(\mathrm{mmHg}) \\
\text { mean } \pm \text { SD }\end{array}$ & $111.6 \pm 6.88$ & $150.08 \pm 11.00^{*}$ \\
\hline $\begin{array}{l}\text { Diastolic BP }(\mathrm{mmHg}) \\
\text { mean } \pm \text { SD }\end{array}$ & $78.08 \pm 6.39$ & $103.12 \pm 10.75^{*}$ \\
\hline $\begin{array}{l}\text { MAP (mmHg) } \\
\text { mean } \pm \text { SD }\end{array}$ & $89.25 \pm 5.68$ & $118.77 \pm 10.84$ \\
\hline
\end{tabular}

$* \mathrm{P}<0.01$ as compared to normal control

Table 2: Lipid profile in normal pregnancy, pre-eclampsia (mild \& severe) \& eclampsia.

\begin{tabular}{|lllll|}
\hline Parameters & $\begin{array}{l}\text { Controls } \\
\text { mean } \pm \text { SD }\end{array}$ & $\begin{array}{l}\text { Mild pre-eclampsia } \\
\text { mean } \pm \text { SD }\end{array}$ & $\begin{array}{l}\text { Severe pre-eclampsia } \\
\text { mean } \pm \text { SD }\end{array}$ & $\begin{array}{l}\text { Eclampsia } \\
\text { mean } \pm \text { SD }\end{array}$ \\
\hline Triglycerides $(\mathrm{mg} / \mathrm{dl})$ & $130.95 \pm 44.64$ & $156.22 \pm 66.57$ & $168.30 \pm 68.14$ & $224.89 \pm 84.40$ \\
\hline Total cholesterol $(\mathrm{mg} / \mathrm{dl})$ & $181.37 \pm 40.3$ & $223.80 \pm 66.75$ & $206.98 \pm 52.84$ & $209.51 \pm 59.10$ \\
\hline HDL cholesterol $(\mathrm{mg} / \mathrm{dl})$ & $55.75 \pm 13.13$ & $59.14 \pm 11.77$ & $57.49 \pm 12.89$ & $54.22 \pm 13.31$ \\
\hline LDL cholesterol $(\mathrm{mg} / \mathrm{dl})$ & $99.00 \pm 40.85$ & $136.22 \pm 60.64$ & $111.91 \pm 48.23$ & $127.75 \pm 93.08$ \\
\hline
\end{tabular}

\section{DISCUSSION}

In this study we investigated the role of lipid profile in the occurrence of pre-eclampsia and eclampsia. There was a positive correlation between Preeclampsia and lipid parameters as shown in Table 2. Serum triglyceride concentration raised more significantly in pre-eclampsia in our study which corroborated with the findings of many workers. $^{8,9}$ The principle modulator of this hypertriglyceridemia is estrogen as pregnancy is 
associated with hyperoestrogenaemia. Estrogen induces hepatic biosynthesis of endogenous triglycerides, which is carried by VLDL. ${ }^{10}$ This process may be modulated by hyperinsulinism found in pregnancy. ${ }^{11}$ Increased TG, found in pregnancy induced hypertension, is likely to be deposited in predisposed vessels, such as the uterine spiral arteries and contributes to the endothelial dysfunction, both directly and indirectly through generation of small, dense LDL. ${ }^{12}$ Moreover, this hypertriglyceridemia may be associated with hypercoagulability ${ }^{13}$. In our study, in contrast to normal pregnant women, the rise in serum TG was statistically significant $(\mathrm{P}<0.05)$ in pre-eclamptic patients \& eclamptic patients.

In present study no significant alteration in other lipid profile parameters observed in normal pregnancy \& in any of the groups. These findings are similar to Sattar et al. ${ }^{12}$ However others have found significant increase in serum TC in toxemia of pregnancy. ${ }^{11-15}$

In summary, the findings reported in this study suggest that the women who develop pre-eclampsia and eclampsia had disturbed lipid profile due to abnormal lipid metabolism. Increased triglycerides levels and delayed triglycerides clearance and high blood pressure are the reasons for the development of preeclampsia \& eclampsia. This association may be significant in understanding the pathological process of pre-eclampsia and may help in developing strategies for prevention and early diagnosis of pre-eclampsia and eclampsia.

\section{ACKNOWLEDGEMENTS}

Authors would like to thank colleagues in the department for their help.

Funding: No funding sources

Conflict of interest: None declared

Ethical approval: The study was approved by the Institutional Ethics Committee

\section{REFERENCES}

1. Kamath S. Hypertension in pregnancy. JAPL. 2006;54:269-70.

2. Vanderjagt DJ, Patel RJ, EI-Nafaty AU, Melah GS, Crossey MJ, Glew RH. High density lipoprotein and homocysteine levels correlate inversely in preeclamptic women in northern Nigeria. Acta Obstet Gynaecol Scand. 2004;83(6):536-42.

3. Dutta DC. Hypertensive disorders in pregnancy. In: Konar HL, eds. Textbook of Obstetrics. 5th ed. New
Delhi: Jaypee Brothers Medical Publishers; 2001: 234-55.

4. Packer CS. Biochemical markers \& physiological parameters as indices for identifying patients at risk of developing pre-eclampsia. J Hypertens. 2005;23(1):45-6.

5. Caren G, Solomon, Seely EW. Pre-eclampsia searching for cause. New Eng J Med. 2004;350(7):641-2.

6. Riza M, Ali Benian, Gümüştaş K, Uzun H, Ocak V, Aksu F. Lipid peroxidation and antioxidants in preeclampsia. Eur J Obst Gynaecol Reprod Biol. 1999 Aug;85(2):205-8.

7. Kokia E, Barkai G, Reichman B, Segal P, Goldman B, Mashiach S. Maternal serum lipid profile in pregnancies complicated by hypertensive disorders. J Perinat Med. 1990;18:473-8.

8. Enquobahrie DA, Williams MA, Butler CL, Frederick IO, Miller RS, Luthy DA. Maternal plasma lipid concentrations in early pregnancy and risk of preeclampsia. Am J Hypertens. 2004;17(7):574-81.

9. Cekmen MB, Erbagci AB, Balat A, Duman C, Maral $\mathrm{H}$, Ergen $\mathrm{K}$, et al. Plasma lipid and lipoprotein concentrations in pregnancy induced hypertension. Clin Biochem. 2003;36(7):575-8.

10. Glueck CJ, Pallet RW, Scheel D. Effects of oestrogenic compounds on triglyceride kinetics. Metabolism. 1975;24:537-45.

11. Adegoke OA, lyare EE, Gbenebitse SO. Fasting plasma glucose and cholesterol levels in pregnant Nigerian women. Niger Postgrad Med J. 2003;10(1):32-6.

12. Sattar N, Bendomir A, Berry C, Shepherd J, Greer IA, Packard CJ. Lipoprotein sub fraction concentrations in preeclampsia: pathogenic parallels to atherosclerosis. Obstet Gynaecol. 1997;89(3):4038.

13. Kokia E, Barkai G, Reichman B, Segal P, Goldman B, Mashiach S. Maternal serum lipid profile in pregnancies complicated by hypertensive disorders. J Perinat Med. 1990;18(6):473-8.

14. Yamaguchi K. Triglycerides and apoproteins in toxaemia of pregnancy. Nippon Sanka Fujika Gakkai Zasshi. 1988;40(2):1875-82.

15. Hubel CA, Lyall F, Weissfeld L, Gandley RE, Roberts JM. Small low-density lipoproteins and vascular cell adhesion molecule-1 are increased in association with hyperlipidemia in pre-eclampsia. Metabolism. 1998;47(10):1281-8.

DOI: $10.5455 / 2320-1770 . i j r \operatorname{cog} 20140981$

Cite this article as: Mittal M, Kulkarni CV, Panchonia A, Mittal RK. Evaluation of serum lipid profile in cases of pre-eclampsia and eclampsia. Int J Reprod Contracept Obstet Gynecol 2014;3:732-4. 